\title{
Changes in Phenol Level and Antioxidant Activity of Cocoa Beans
}

\section{During Fermentation and Roasting}

\author{
St Sabahannur ${ }^{1}$, Suraedah Alimuddin ${ }^{1} \&$ Rahmawati $^{2}$ \\ ${ }^{1}$ Dept. Agrotechnology, Faculty of Agriculture, University of Muslim Indonesia, Indonesia \\ ${ }^{2}$ Faculty of Pharmacy, University of Muslim Indonesia, Indonesia \\ Correspondence: St. Sabahannur, Dept. Agrotechnology, Faculty of Agriculture, University of Muslim Indonesia, \\ Indonesia. E-mail: siti_sabahan@yahoo.com
}

\author{
Received: February 2, 2018 Accepted: March 27, 2018 Online Published: May 20, 2018 \\ doi:10.5539/jfr.v7n4p23 \\ URL: https://doi.org/10.5539/jfr.v7n4p23
}

\begin{abstract}
Flavonoid, polyphenols, especially catechin and epicatechin,are major components in cocoa products, which are known for antioxidant properties. Cocoa bean requires fermentation process in order to obtain good taste. During the fermentation process, polyphenols are oxidized by polyphenol oxidase to form quinone and 2-quinon. The purpose of the research is to determine the total level of polyphenol and antioxidant activity of fermented and roasted cocoa beans. The experiment was using Completely Randomized Design (CRD) with fermentation treatment that includes: Without fermentation, three-day fermentation and five-day fermentation. Observation parameters include: Polyphenol level and antioxidant activity with DPPH method. The results showed that the total phenol level of cocoa bean changed during fermentation and after roasting. The highest phenol level was found in cocoa beans without fermentation, and there is a decrease of phenol level to $98 \%$ after fermentation and roasting. The fermentation affects the Inhibition Concentration $\left(\mathrm{IC}_{50}\right)$ of cocoa beans. An unfermented bean showed a very strongly active antioxidant activity with $\mathrm{IC}_{50}$ of $7.848 \mathrm{ppm}$, whereas three-day fermentation showed a strong antioxidant activity with $\mathrm{IC}_{50}$ of $35.961 \mathrm{ppm}$, and five-day fermentation is moderately active with $\mathrm{IC}_{50}$ of $55.976 \mathrm{ppm}$.
\end{abstract}

Keywords: cocoa beans, fermentation, poliphenol, antioxidant activity, DPPH

\section{Introduction}

One of plantation crops that the product is widely used in industrial world is cocoa bean (Theobroma cacao L.), because it can be processed into various products with high economic value. Nowadays cocoa products have a lot of attention because it contains a high amount of antioxidant, they even have greater potential than tea and some fruits products that have been known as a source of natural antioxidants(Wilkinson, 1999).

Cocoa contains various polyphenolic compounds stored in the pigment cells of cotyledons (Counet et al., 2004, Wollgast, 2004). The amount of polyphenol in cocoa beans reaches about 6-8\% (Zumbe, 1998), it can even reach $10 \%$ of the dry weight (Rusconi; Conti, 2010). In addition, cocoa beans contain phenolic compounds such as: catechin, epicatechin, proanthocyanidin, phenolic acid, tannins and other flavonoids. Of this amount, it turns out that flavanol is found in highest quantities in cocoa beans when compared to other types of flavonoids. Cocoa beans have potential as a natural antioxidant ingredients, which we all know that antioxidant could modulate modulate the immune system, prevention of coronary heart, cancer, and as antibacterial (Othman et al. 2007, Weisburger, 2001, Keen et al. 2005., Marsaban, 2007, Sartini et al. 2011). Thus a high level of antioxidant activity makes cocoa could be developed into a healthy product.

Cocoa beans still contain polyphenol although the concentration of polyphenol is decreasing during fermentation and drying. This polyphenol causes bitter and astringent tastes. During fermentation the total amount of phenolic compounds decreased as much as $70 \%$. The sharp decline can be observed between the second and third day, when the seed dies. It is caused when the seeds begin to enter the fermentation of 24-28 hours (dead seeds), polyphenols diffuses from cells then undergo polymerization, oxidation and interactions with proteins.

The next stage of the process after drying, cocoa beans are roasted in $120-140^{\circ} \mathrm{C}$ for about 45 minutes. Roasting may damage polyphenols and this process could reduce the bitter and astringent tastes in cocoa beans. In such 
conditions polyphenolic compounds changed much because of their prolonged exposure to oxygen at relatively high temperatures. The heating process performed causes structural changes of stereoisomers flavanol that may result in changes in antioxidant activity. The benefit of antioxidant product is determined by the level of antioxidant activity.

Measuring the antioxidant activity of intermediate products is needed to determine how much antioxidant potency before and after processed into foods. The method of measurements of the antioxidant activity will detect the different characteristics of the antioxidants in the sample.

Results of a research conducted by Redovnikovic et al. (2009) used two different methods of measuring antioxidants, that is, ORAC (Oxygen Radical Antioxidant Capacity) and DPPH (1,1'-diphenyl-2-picrylhydrazyl), showed that the total polyphenol content in cocoa positively associated with antioxidant activity in both methods.

In this research, the measurement of antioxidant activity will be performed with DPPH (2,2-diphenyl-1-picrylhydrazyl). The advantages of the DPPH test method is that it is already widely used in the world and is easy to implement because of the radical compound used is relatively stable compared to other methods (Hartanto, 2012). The purpose of the research is to determine the levels of polyphenols and antioxidant activity of cocoa beans after fermentation and roasting with DPPH (2,2-diphenyl-1-picrylhydrazyl) method.

\section{Experimental Methods}

The ripe cocoa pods are split, then the seeds are removed, next fermented in wooden box. Fermentation is performed with: unfermented cocoa beans, three-day and five-day fermented seeds,. When the fermentation is complete, the cocoa beans are dried until the water content reaches 6-7\%.

\section{Observation Parameter:}

\subsection{Determination of Polyphenols (Lee et al. 2003)}

Making of Standard Solution of Tanat Acid. Standard solution with $100 \mathrm{ppm}$ is made by weighing $10 \mathrm{mg}$ of tannic acid, dissolved with distilled water up to $100 \mathrm{~mL}$. After that, a series of concentration is made, which are 5, $10,15,20,25 \mathrm{ppm}$. Next is determination of Maximum Wavelength $(\lambda \max )$. It is performed by measuring the solution of $10 \mathrm{ppm}$ tannic acid in the wavelength range of $600-800 \mathrm{~nm}$. The measurement showed that the maximum wavelength is $769.87 \mathrm{~nm}$.

- Measurement of Tanat Acid Standard Solution

Tannic acid solution with a concentration of 5, 10, 15, 20, $25 \mathrm{ppm}$ each is pipetted $1 \mathrm{~mL}$ and added with 0.5 $\mathrm{mL}$ of Folin, and mixed with vortex method for 2 minutes, then added $2 \mathrm{~mL}$ of $7 \%$ natrium carbonate then mixed with vortex method and incubated for 30 minutes. Absorbance is measured at a wavelength of 769.87 $\mathrm{nm}$.

- Making of Sample Solution of Cocoa Beans Ethanol Extract

This step is done by weighing $10 \mathrm{mg}$ of ethanol extract of cocoa beans that is dissolved in distilled water up to $10 \mathrm{~mL}$, pipettedas much as $1.25 \mathrm{~mL}, 5 \mathrm{~mL}$ inserted into the flask until the concentration reaches $250 \mathrm{ppm}$.

- Determination of total flavonoid of cocoa beans ethanol extract.

$1 \mathrm{~mL}$ ethanol extract of cocoa beans is pipetted and added by $0.5 \mathrm{~mL}$ of Folin, and mixed with vortex method for 2 minutes, then added $2 \mathrm{~mL}$ of $7 \%$ Sodium carbonate then mixed with vortex method and incubated for 30 minutes. Absorbance is measured at $769.87 \mathrm{~nm}$ wavelength. Replication is performed 3 times.

2.2 Testing of Antioxidant Activity is Performed with DPPH Method as Practiced Modified (Othman et al. 2007)

\section{Preparation of DPPH}

- DPPH solution of $0.4 \mathrm{~mm}$ is made by weighing $15.7 \mathrm{mg}$ of DPPH powder then diluted with $100 \mathrm{ml}$ of ethanol (p.a) in a volumetric flask. The measurement of maximum wavelength is performed by pipetting 1 $\mathrm{mL}$ DPPH solution and added by $3.5 \mathrm{ml}$ of (p.a) ethanol then incubated for $30 \mathrm{~min}$ at $30^{\circ} \mathrm{C}$ and the absorbance is measured at $450-800 \mathrm{~nm}$ wavelength.

- Preparation and measurement of antioxidant potency of quercetin comparator sample.

Standard solution of $1000 \mathrm{ppm}$ is made by weighing $10 \mathrm{mg}$ quercetin, diluted with ethanol (p.a) up to $10 \mathrm{~mL}$. Then $100 \mathrm{ppm}$ of standard solution is made by pipetting $0.5 \mathrm{~mL}$ of $1000 \mathrm{pm}$ standard solution until it reached $5 \mathrm{~mL}$. After that, a series of concentration $(4,6,8,10,12 \mathrm{ppm})$ is made,. Testing is performed with pipetting $1 \mathrm{~mL}$ of standard solution from various concentrations and then each is added with $0.4 \mathrm{~mm}$ of DPPH then added $2.5 \mathrm{ml}$ of ethanol (p.a). Solution is incubated at $37^{\circ} \mathrm{C}$ for 30 minutesand measured at $515.97 \mathrm{~nm}$ wavelength. 
- Preparation and measurement of antioxidant potency of cocoa beans ethanol extract

$1000 \mathrm{ppm}$ of stock solution is made by weighing $25 \mathrm{mg}$ of the ethanol extract of cocoa beans and dissolved with ethanol (p.a) up to $25 \mathrm{ml}$ in a flask. Then various concentrations of 500, 600, 700, 800, $900 \mathrm{ppm}$ is made. Testing is performed by pipetting $1 \mathrm{~mL}$ of various concentrations and then each is added DPPH 0.4 $\mathrm{mm}$ then added $2.5 \mathrm{~mL}$ of ethanol (p.a). Solution, incubated at $37^{\circ} \mathrm{C}$ for 30 minutes and measured at a wavelength of $515.97 \mathrm{~nm}$. The amount of the antioxidant strength is calculated using the formula (Othman et al. 2007):

$$
\% \text { inhibition }=\left(\frac{\text { blank Absorbance }- \text { sample Absorbance }}{\text { blank Absorbance }}\right) \times 100 \%
$$

$\mathrm{IC}_{50}$ is calculated by plotting scavenging activity graphs with concentrations of the extract, which is defined as the total antioxidant needed to lower the concentration of DPPH to $50 \%$.

\section{Results and Discussion}

\subsection{Results}

\section{a. Phenol Content in Cocoa Beans After Fermented}

During fermentation, there would occur decomposition of polyphenol, protein and sugar compounds in cocoa beans by the enzymes that would produce aroma candidate compounds, taste improvement and color change. Determination of total phenol content of dry beans was performed using the Folin-Ciocalteu method. The use of tannic acid which is a component of the phenol as a standard would predict phenol level in cocoa beans. Phenol content of fermented dry cocoa beans can be seen in Figure 1.

ANOVA testing $(\alpha=0.01)$ showed that the fermentation time of cocoa beans affects the phenol level significantly. Unfermented cocoa beans had the highest phenol content, while the 5-day fermentation of cocoa beans contained the lowest, but not significantly different from the phenol level of 3-day fermentation of cocoa beans. Phenol level decreased by approximately $50 \%$ after fermentation.

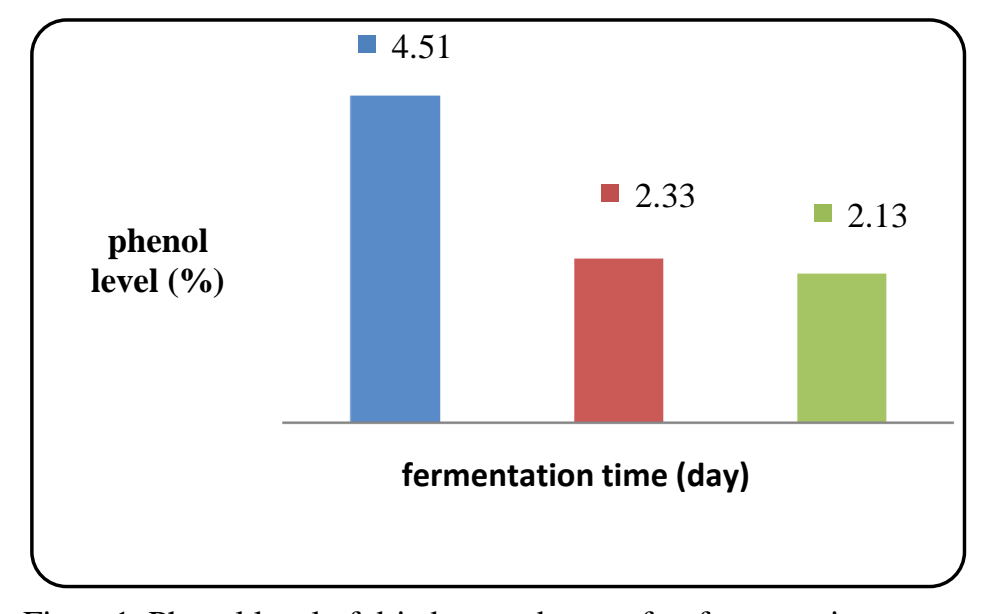

Figure1. Phenol level of dried cocoa beans after fermentation

Figure 1 shows the total phenol content of unfermented cocoa beans is 5,00\% and decreased by $50 \%$ in 3 days of fermentation (2.33\%) and 5 days to $2.13 \%$.

\section{b. Total Phenol of Cocoa Beans After Roasting}

Fermented cocoa beans were dried, then roasted at temperature of $120^{\circ} \mathrm{C}$ for 40 minutes.ANOVA test showed that roasting significantly affected the phenol content of cocoa beans. Roasting led to decrease of phenol level in cocoa beans. This is proved from the test which shown that the unfermented cocoa beans had the highest phenol level $(0.534 \%)$, while the five days fermented cocoa beans had the lowest phenol level $(0.195 \%)$. 


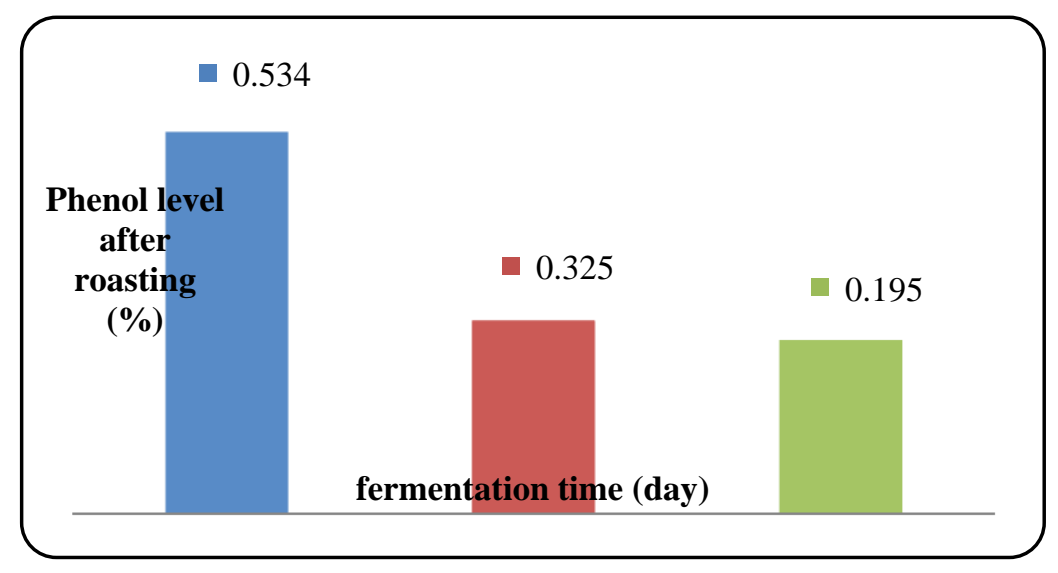

Figure 2. Total phenol content after roasting

Figure 2 shows the phenol level declined very sharply after roasting. The magnitude of the decline rate of phenol level reached an average of $98 \%$, both fermented and unfermented beans.

\section{c. Testing of Antioxidant Activity}

Measurement of cocoa beans extract absorbance carried out at a wavelength of $517 \mathrm{~nm}$, Absorbance resulted was then converted intoInhibition Concentration $\left(\mathrm{IC}_{50}\right)$. The measurement results can be seen in Table 1 .

Table 1. The antioxidant activity of cocoa bean and quercetin extract using DPPH

\begin{tabular}{ccccccc}
\hline \multirow{2}{*}{ Fermentatio (day) } & \multicolumn{6}{c}{ Concentration (ppm) } \\
\cline { 2 - 7 } & 10 & 20 & 30 & 40 & 50 & $\mathrm{IC}_{50}$ \\
\hline 0 & 44.780 & 67.931 & 89.699 & 94.118 & 95.874 & $7.958 \mathrm{a}$ \\
3 & 34.324 & 39.944 & 44.517 & 56.155 & 58.111 & $36.926 \mathrm{~b}$ \\
5 & 30.288 & 36.351 & 38.635 & 43.890 & 55.986 & $56.986 \mathrm{c}$ \\
\hline \multirow{2}{*}{ Quercetin/concentration } & 0.5 & 1 & 2 & 3 & 4 & \\
\cline { 2 - 7 } & 31.942 & 38.653 & 43.235 & 49.764 & 55.257 & 2.996 \\
\hline
\end{tabular}

Table 1 shows the fermentation time significantly affect the $\mathrm{IC}_{50}$ value of cocoa beans. Unfermented cocoa beans have $\mathrm{IC}_{50}$ value of 7.958 , whereas the fermented cocoa beans obtained higher values. The $\mathrm{IC}_{50}$ highest value was shown in the 5-days fermented cocoa beans.

\subsection{Discussion}

\section{Polyphenol}

The content of polyphenol and antioxidant activity in the unfermented cocoa beans is higher than in the fermented cocoa beans (Prayoga, Murwani, \& Anwar, 2013), because oxidation, polymerization, and protein binding process could reduce the polyphenol level in cocoa beans during fermentation (Nazaruddin et al., 2006). In general, the fermentation process of cocoa beans may take between 5 to 7 days, and there are two processes, namely external and internal fermentation. External fermentation is the process of sugar catabolism by microorganisms, whereas internal fermentation includes biochemical processes into the seed cotyledons. During the fermentation process, polyphenol compounds disperse out of their storage cells and then undergo oxidation that forms high molecular compounds (Bernaert et al., 2012). As shown in Figure 1, phenol content of cocoa beans changes during the fermentation process. The highest value of total phenol content was found in unfermented cocoa beans with the value of $4.51 \%$ and a phenol content decreased after fermented for 3 days with values of $2.33 \%$ and to $2.13 \%$ after 5 days of fermentation. The decrease in phenol levels during fermentation was suspected caused by the hydrolysis and oxidation of phenolic compounds during the fermentation process. The decline is due to the oxidation of polyphenols by the activity of the oxidase polyphenol enzyme (PPO). The oxidase polyphenol enzyme is an enzyme that is essential in the process of oxidation of polyphenol compounds in cocoa. The enzyme started working during the fermentation process and continued until the early stages of the drying process(Abdulamir et al. 2012).

All the processes that occur caused a significant reduction in polyphenol content of the seed. The amount of 
cocoa polyphenols, especially (-) - epicatechin was reported decreased by $90 \%$ or more during the fermentation and drying (Kim \& Keeney, 1984; Pettipher, 1986; Wollgast and Anklam, 2000). The content of polyphenols decreased sharply in the second and third day when the seed died.When the seeds began entering the fermentation of 24-28 hours (dead seeds), polyphenols diffused from cells that subsequently underwent polymerization and oxidation. Oxidase polyphenol achieved optimal activity at $\mathrm{pH} 6$ and temperature of $35.5^{\circ} \mathrm{C}$ (Lopez and Dimick, 1995; Misnawi and Selamat, 2003). The oxidase polyphenol enzyme activity would decrease rapidly towards the end of fermentation, it might be caused due to an increase in temperature, and oxidase polyphenol would not be active when the beans are dried (Lopez and Dimick, 1995; Afoakwa et al. 2012).

After drying, the cocoa beans are roasted in $120-140^{\circ} \mathrm{C}$ for approximately 40 minutes. Figure 2 shows that the phenol level in both fermented and unfermented cocoa beans could decrease up to $98 \%$ after roasting. During roasting polyphenols was damaged so that bitter and astringent taste are reduce. In such conditions polyphenolic compounds might change much since long exposed to oxygen at relatively high temperature. The heating process performed caused structural changes of stereoisomer flavonoids that might result in changes in antioxidant activity. Till nowadays, roasting of cocoa beans are still performed conventionally with the rate of transferred heat is limited to three standard ways, which are conduction, convection and radiation. These method led to slow heating process. In such circumstance, polyphenolic compounds changed much since the prolonged contamination to oxygen at relatively high temperature, so it affects the antioxidant activity (Supriyanto et al. 2006)

\section{Antioxidant Activity}

Antioxidant testing of phenolic compounds can be performed by using DPPH radical. Essential structure required for anti-radical activity was the presence of free electrons species. Compound having a hydrogen atom that can be released easily can react with DPPH radical. Most antioxidant compounds were known to possess phenol group that can easily donate hydrogen radical to the DPPH radical (Makhmoor, 2005; Shetty and Wahqvist, 2004). The antioxidant activity is the ability of a compound or extract to inhibit the oxidation reaction which can be expressed as inhibition percentage. Parameters used to indicate the antioxidant activity is efficient concentration $\left(\mathrm{EC}_{50}\right)$ or Inhibition Concentration $\left(\mathrm{IC}_{50}\right)$ which is an antioxidant concentration that can cause $50 \%$ of DPPH lost its radical character. As stated by Brand-Williams et al. (1995), substances that have a high antioxidant activity, would have a lower $\mathrm{EC}_{50}$ or $\mathrm{IC}_{50}$.

The antioxidant compound will react with the DPPH radical through a hydrogen atom donation mechanism and cause color discoloration of DPPH from purple to yellow as measured at a wavelength of $517 \mathrm{~nm}$ (Hanani et al., 2005, Rahayu et al. 2009). The incubation time for 30 minutes at $37^{\circ} \mathrm{C}$ was required to ensure the DPPH radical works. Inhibition Concentration $\left(\mathrm{IC}_{50}\right)$ is the concentration of an antioxidant substance that can cause $50 \%$ DPPH to lose the radical character or in other words, it is a concentration of an antioxidant substance that gives $50 \%$ inhibition (Suratmo, 2008).

The $\mathrm{IC}_{50}$ values of cocoa beans extract from the three treatments are: unfermented has $7.848 \mathrm{ppm}$ classified as very strongly active, 3-days fermentation amounted to $35.961 \mathrm{ppm}$ classified as strongly active, and 5-days fermentation has $55.976 \mathrm{ppm}$ that is classified as moderately active. The lower the $\mathrm{IC}_{50}$ value of a sample, the higher the antioxidant activity. Deterrence activities of DPPH free radicals of the cocoa bean extract of the three treatments compared to quercetin as standard showed that extracts of cocoa beans were smaller than the quarsetin comparator which is $2.896 \mathrm{ppm}$, and categorized as "very strongly active". Bioactive compounds can be classified based on the $\mathrm{IC}_{50}$ value. Value of $\mathrm{IC}_{50}>250 \mathrm{ppm}$ is classified as "inactive"; $100-250 \mathrm{ppm}$ as "weakly active"; 50-100 ppm as "moderately active"; $10-50$ ppm as "strongly active" and <10 ppm as "very strongly active" (Phongpaichit et al. 2013).

\section{Conclusion}

The fermentation, drying, and roasting of cocoa beans interacted with one another in influencing the level of polyphenols and antioxidant activity. The process of fermentation and roasting of cocoa beans can decrease the polyphenol content by $98 \%$. In addition, fermentation and roasting greatly affect the antioxidant activity of cocoa beans, compared to unfermented cocoa beans. Beside that, fermentation and roasting highly affect the antioxidant activity of cocoa beans. Cocoa beans that were not fermented showed a very strongly active antioxidant activity with $\mathrm{IC}_{50} 7.848 \mathrm{ppm}$, while the 3-day fermentation showed a strong antioxidant activity with $\mathrm{IC}_{50} 35.961 \mathrm{ppm}$ and 5-day fermentation showed moderately active with $\mathrm{IC}_{50} 55.976 \mathrm{ppm}$. 


\section{Acknowledgments}

The authors would like to thank the Ministry of Research and Technology and Higher Education who have funded the research in the Competitive Grant scheme so that this research can be done.

\section{References}

Abdulamir,D, N. M., A. S., Khatib, A., \& Sabu, M. C. (2012). Antioxidant Activity Of Different Extracts From Leaves of Pereskia Bleo(Cactaceae), Journal Of Medicinal Plants Research, 6(15), 2932-293.

Afoakwa, E. O., Quao, J., Takrama, J., Budu, A. S., \& Saalia, F. K. (2012). Influence of pulp preconditioning and fermentation on fermentative quality and appearance of Ghanaian cocoa (Theobroma cacao) beans. International Food Research Journal, 19(1), 127-133.

Bernaert, H., Blondeel, L., Allegaert, L., \& Lohmueller, T. (2012). Industrial Treatment of Cocoa in Chocolate Production: Health Implications. In book: Chocolate and Health. First ed. Editor: Paoletti, R., Poli, A., Conti, A., Visioli F. Springer-Verlag Italia.

Brand-Williams, W., Cuvelier, M. E., \& dan Berset, C. (1995). Use of a free radical method to evaluate antioxidant activity. Lebensmittel-Wissenschaft und-Technologie, 29, 2530. https://doi.org/10.1016/S0023-6438(95)80008-5

Counet, C., Ouwerx, C., Rosoux, D., \& Collin, S. (2004). Relationship Between Procyanidin Andflavor Contents of Cocoa Liquors From Different Origins. J. Agric. Food Chem, 52, 6243-6249. https://doi.org/10.1021/jf040105b

Hanani, E., Mun'im, A., \& dan Sekarini, R. (2005). Identifikasi Senyawa Antioksidan dalam Spons Callyspongia SP dari Kepulauan Seribu, Majalah Ilmu Kefarmasian, 2(3), 130.

Hartanto, H. (2012). Identifikasi Potensi Antioksidan Minuman Cokelat Dari Kakao Lindak (Theobroma cacao L.) Dengan Erbagai Cara Preparasi: Metode Radikal Bebas 1,1Diphenyl-2-Picrylhydrazil (DPPH).[Skripsi]. Fakultas Teknologi Pertanian. Universitas Katolik Widya Mandala, Surabaya.

Keen, C. L., Holt, R. R., Oteiza, P., Fraga, C., \& Schmitz, H. H. (2005). Cocoa AntioxidantAnd Cardiovascular Health. Am. J. Clin. Nutrition, 81(1), S298-S303. https://doi.org/10.1093/ajcn/81.1.298S

Kim, H., \& Keeney, P. G. (1984). Epicatechin Content in Fermented And Unfermented CocoaBeans. Journal of Food Science, 49, 1090-1092. https://doi.org/10.1111/j.1365-2621.1984.tb10400.x

Lee, K. W., Kim, W. J., Lee H. J., \& Lee, C. Y. (2003). Cocoa Has More PhenolEC PhytochemECals and a Higher Antioxidat Capacity than Teas and Red Wine, Journal of AgrECultural Food Chemistry, 51, 7292-7295. https://doi.org/10.1021/jf0344385

Lopez, A. S., \& Dimick, P. S. (1995). Cocoa Fermentation. In: Reed, G., Nagodawithana TW. (Eds), Enzymes, Biomass, Food And Feed. VCH, Weinheim: Pp. 561-577.

Makhmoor. T. (2005). Antioksidan from medicinal plants and synthetic origin. PhD Dissertation. H.E.J. Research Institute of Chemistry International Centre for Chemical Science. University of Karachi, Pakistan.

Marsaban (2007). Perbandingan Efek Antibakterial Ekstrak Buah Cacao (Theobroma cacao) Pada Berbagai Konsentrasi Terhadap Streptococcus Mutans, Artikel Penelitian Fakultas Kedokteran Universitas Diponegoro, Semarang.

Misnawi Dan Selamat (2003). Effect of Cocoa Bean Polyphenols on Sensory Properties and Their Changes during Fermentation, Pelita Perkebunan, 19(2), 90-103.

Nazaruddin, R., Seng, L. K., Hassan, O., \& Said, M. (2006). Effect of pulp preconditioning on the content of polyphenols in cocoa beans (Theobroma Cacao) during fermentation. Industrial Crops and Products, 24(1), 87-94. https://doi.org/10.1016/j.indcrop.2006.03.013

Othman, A., Ismail, A., Ghani, N. A., \& Adenan, I. (2007). Antioxidant Capacity And Phenolyc Content Of Cocoa Beans, Journal of Food Chemistry, 100, 1523-1530. https://doi.org/10.1016/j.foodchem.2005.12.021

Pettipher, G. L. (1986). An Improved Method For The Extraction And Quantitation Of Anthocyanins In Cocoa Beans And Its Use As An Index Of The Degree Of Fermentation. Journal of the Science of Food and Agriculture, 37, 289-296. https://doi.org/10.1002/jsfa.2740370314

Phongpaichit et al. (2017). Biological Activities of Extract from Endophytic Fungi Isolated from Garcinia plants, Wiley Online Library. 
Rahayu, M. S., Wiryosoendjoyo, K., \& Prasetyo, A. (2009). Uji aktivitas antibakteri ekstrak sokletasi dan maserasi buah Makasar terhadap bakteri Shigella dysentriae ATCC 9361 secara in vitro. Biomedika, 2(1), 40-46.

Prayoga, R. D., Murwani, R., \& Anwar, S. (2013). Polyphenol axtracts from low quality cocoa beans: antioxidant, antibacterial and food colouring properties. Internat.Food Res. J., 20(6), 3275-3281.

Redovnikovic, I. R., Delonga, K., Mazor, S., Dragovic-Uzelac, V., Caric, M., \& Vorkapic-Furac, J. (2009). Polyphenolic Content And Composition And Antioxidative Activity Of Different Cocoa Liquors, Czech Journal Of Food Science, 27(5), 330-337. https://doi.org/10.17221/119/2008-CJFS

Rusconi, M., \& Conti, A. (2010). Theobroma cacao L., The Food of the Gods: A Scientific Approach beyond Myths and Claims. J. Pharmacological Research, 61(1), 5-15.

Sartini, Djide, Natsir, M., \& Alam, G. (2011). Ekstraksi Komponen Bioaktif Dari Limbah Kulit Buah Kakao Dan Pengaruhnya Terhadap Aktivitas Antioksidan Dan Antimikroba, Journal of Traditional Medicine, 14(47).

Wollgast, J. E., Anklam (2000). Polyphenols In Theobroma Cacao: Changes In Composition During The Manufacture Of Chocolate And Methodology For Identification And Quantification: A Review, Food Res. Int., 33, 423-447.

Shetty, K., \& Wahqvist, M. (2004). A Model For Role Of Proline-Linked Pentose Phosphate Pathway In Phenolic Phytochemical Biosynthesis And Mechanism Of Action For Human Health And Environmental Application. Asia Pacific. J. Clinic. Nutrition, 13, 1-24

Supriyanto; Haryadi: Budi Rahardjo; dan Djagal Wiseso Marseno (2006). Aktivitas Antioksidan Ekstrak Polifenol Kasar Dari Kakao Hasil Penyangraian Menggunakan Energi Gelombang Mikro. J. Teknol. Dan Industri Pangan.Vol.XVII No3 Th. 2006.

Suratmo, (2008). Potensi Ekstrak Daun Sirih Merah Sebagai AntioksidanUniversitas Brawijaya, Malang

Weisburger, J. H. (2001). Chemopreventive Effects Of Cocoa Polyphenols On Chronic Diseases. Experimental Biology and Medicine, 226, 891-897. https://doi.org/10.1177/153537020122601003

Wilkinson, S. L. (1999). Take Two Cups of Coffee and Call Me Tomorrow. Coffee and Chocolate Contain Antioksidans That May Promote Health. Chemical and Engineering News. April 12, 47-50.

Wollgast, J. (2004). The Contents and Effects of Polyphenols in Chocolate. Dissertation For Obtaining The Degree Of Doctor Of The Faculty Of Agricultural And Nutritional Sciences, Home Economics And Environmental Management At The University Of Gieben, Germany.

Zumbe, A. (1998). Polyphenols In Cocoa: Are There Health Benefits? British National Formulary. Nutrition Bulletin, 23, 94-102. https://doi.org/10.1111/j.1467-3010.1998.tb01088.x

\section{Copyrights}

Copyright for this article is retained by the author(s), with first publication rights granted to the journal.

This is an open-access article distributed under the terms and conditions of the Creative Commons Attribution license (http://creativecommons.org/licenses/by/4.0/). 